\title{
Root attributes and seedling biomass of old and modern soybean cultivars under water deficit
}

\author{
Renan Caldas Umburanas ${ }^{1 *}$, Victória Cordeschi Donegá1, Vanessa Mendes de Queiroz', \\ Daniele Cristina Fontana', Daiana Bampi'1, Durval Dourado-Neto', Klaus Reichardt²
}

${ }^{1}$ Luiz de Queiroz College of Agriculture (ESALQ), University of São Paulo (USP), Piracicaba 13418-900, Brazil, ${ }^{2}$ Center of Nuclear Energy in Agriculture (CENA), University of São Paulo (USP), Piracicaba 13400-970, Brazil

\section{A B S T R A C T}

\begin{abstract}
The water deficit in the initial soybean root growth may impair the crop establishment and force the grower to perform a re-seeding. This problem has occurred in some producing regions of Brazil and according to the predictions of climate change may become an increasingly frequent condition. Characterizing and identifying cultivars with characteristics of water deficit resilience are important for the development of improved cultivars in the future. Seedlings of four soybean cultivars were evaluated, being two old and two modern, with and without water deficit. The method used in this work evidenced that there is interaction between cultivar and water deficit in the growth of soybean seedlings. This method can be replicated for a mass prospection of cultivars in search of resilience to the water deficit, since it can be evaluated in a short time span. Soybean seedlings evaluated under water deficit condition increased the biomass root partition with different changes in root attributes. The modern cultivars increased the root length in water deficit, evidencing that this characteristic was selected by breeding, even if indirectly. The cultivars used in this study can be classified in relation to the water deficit as follows: sensitive - Santa Rosa; intermediary - Embrapa 48 and BRS 284; and less sensitive TMG 7262.
\end{abstract}

Keywords: Root length; Biomass partition; Climatic changes; Hydric stress

\section{INTRODUCTION}

Soybean (Glycine max) is the main vegetable source of oil and protein in the world, and in the 2017 growing season 353 million tons were produced in the world (FAOSTAT, 2019). Meanwhile, world production needs to grow in the next few years to meet global food demand, which will increase by more than 50 percent from current levels by 2050 (Ray et al., 2013). The world is undergoing climate change and one of the major threats to global agriculture is the rise in global temperature which consequently affects water regimes around the globe. This favors the increase of the susceptibility of drought in several agricultural regions (Dai, 2013; Foyer et al., 2016), including several soybean producing regions in Brazil, Argentina and United States, the major soybean producers in the world (FAOSTAT, 2019). Increasing yield and tackling stress conditions that will intensify in the future will make agriculture more challenging in the coming years.

The water deficit during the initial soybean root growth can harms the establishment of a crop and compels the grower to re-sow. This is already a problem in some producing regions of Brazil and according to the predictions of climate change this can become more frequent (Wheeler and Von Braun, 2013). Thus, characterizing and identifying cultivars with water deficit resilience characteristics is important for the genetic development of cultivars better adapted to such conditions.

During the vegetative growth of the soybean, water deficiency can reduce the plant leaf area due to the reduction of cellular expansion. It also reduces stomatal conductance, photo-assimilate translocation and photosynthesis, resulting in plants with small leaves, reduced stem diameter, and lower plant height (Sediyama et al., 2015; Chaves et al., 2009). Depending on the cultivar, water deficits may induce in the plant physiological, cellular or molecular undesirable adaptations (Chaves et al., 2009).

In this context, the selection of better drought-tolerant soybean cultivars becomes necessary to confront this threat of the food and protein security of the planet (Ku et al., 2013).

\footnotetext{
*Corresponding author:

Renan Caldas Umburanas, Luiz de Queiroz College of Agriculture (ESALQ), University of São Paulo (USP), Piracicaba 13418-900, Brazil.

Phone: +55-19-3429-4148. E-mail: renan.umburanas@gmail.com
}

Received: 30 April 2019; Accepted: 29 August 2019 
Water is the natural resource with the greatest presence in the constitution of plant cells, accounting for 80 to $95 \%$ of fresh tissues and is fundamental in the physical, biological, chemical processes of the plant, diffusion of solutes, and in the development and sustentation of plant tissues (Broetto et al., 2017). For soybeans, water availability is important mainly in two periods of development, that is, germinationemergence and flowering-grain filling stages (Jha et al., 2018).

There is few information on the characterization of root attributes of soybean cultivars, as well as the pronounced genetic effect through the evaluation of different cultivars. Still less information is found in characterizing old soybean cultivars in relation to the more modern soybean cultivars. Moreover, most studies that evaluate the effect of hydric stress or water deficit consider only the attributes observed above the soil surface.

The root system of the soybean is pivoting, constituted by a primary root and lateral roots. Dry biomass growth and root length in soybean plants can be reduced under water deficit conditions (Thu et al., 2014). The water deficit can modify the root architecture, depth, branching density and angle, and the biomass partition (Franco et al., 2011; Fenta et al., 2014). A rapid way for assessing the plant sensitivity to the water deficit is to evaluate the root growth at the seedling stage. Understanding the effect of water deficit on the initial root growth, as well as comparing the effect of different cultivars in this condition is necessary for the development of more resilient cultivars. The objectives of this study were to evaluate how soybean seedlings of different cultivars react to adequate and reduced moisture at germination, in terms of (i) root and shoot attributes, as well as (ii) biomass production.

\section{MATERIALS AND METHODS}

The experiment was carried out in the seed laboratory of the "Luiz de Queiroz" College of Agriculture - Esalq/USP ( $22^{\circ} 42^{\prime} \mathrm{S}, 47^{\circ} 38^{\prime} \mathrm{W}$, altitude $546 \mathrm{~m}$ ). The experimental design consisted of randomized blocks, using four soybean cultivars, with or without water deficit and with 100 replications. The experimental unit consisted of one seedling. The used cultivars and the year of release were: Santa Rosa (1975), Embrapa 48 (1995), BRS282 (2007), and TMG 7262 (2012). The treatments were arranged in trays, with dimensions of $46.5 \times 28.5 \times 9 \mathrm{~cm}$ containing 50 equidistantly spaced seedlings into sieved sand $(2 \mathrm{~mm})$ previously washed. In the treatment without water deficit the initial water content was $70 \%$ of the water retention capacity of the substrate, which is the recommended standard for the test of germination of soybean seeds (Brasil, 2009), while the water deficit treatment was maintained with $35 \%$ of the water retention capacity of the substrate. Seeding was carried out on July $11^{\text {th }}, 2017$, and seeds of high vigor and germination were used. Seed germination was evaluated daily.

Ten days after sowing, the shoots and intact roots were removed of the seedlings from destructive sampling performed by substrate waterlogging and scanned into images at 300 dpi resolution by using an Epson XL 10000 scanner (Fig. 1A). During the scan process, the seedlings root and shoot were submerged into an acrylic container filled with water. Images were evaluated by the WinRhizo software version 4.1c (Regent Instruments) (Fig. 1B). The procedure followed the methodology proposed by Bouma et al. (2000), with adaptations. The analysis was performed based on the Thresholding method, whereby the seedlings were identified by the dark pixels projected on a white background.

The following attributes were evaluated for roots: volume; length; mean diameter; altitude, which is the longest distance between the base of the root and a meristem; meristems; main root length, and projected area. For shoot, the projected area, volume, diameter and height were evaluated. After the evaluations, the cotyledon was discarded from all seedlings and the materials were oven dried for 48 hours at $65^{\circ} \mathrm{C}$, and then the dry biomass of shoot and roots were determined per seedling.

The collected data were submitted to the Shapiro-Wilk test, and fulfilled the normality assumption, submitted to analysis of variance. When $p \leq 0.05$, the treatments were classified by the Tukey test at 5\% of significance (Sisvar software, Ferreira, 2008).

\section{RESULTS}

All studied cultivars showed germination above $90 \%$, and, therefore, were in the required standard for the germination testing (Fig. 2). The analysis of variance of the water condition and cultivars can be observed in Table 1.

Table 1. Analysis of variance between water availability and cultivars for attributes corresponding to root growth, shoot growth and dry biomass.

\section{Root attributes}

The projected area, volume and diameter of roots differed for cultivar and water conditions, without interaction (Fig. 3). The projected area was 1.22 times higher in cultivar TMG7262 than the average of the other cultivars (Fig. 3A). Likewise, plants with water deficit presented roots projected area 1.27 times greater than plants without water deficit (Fig. 3B).

Root volume was higher in cultivar TMG7262, which did not differ from Santa Rosa cultivar (Fig. 3C). Seedlings 


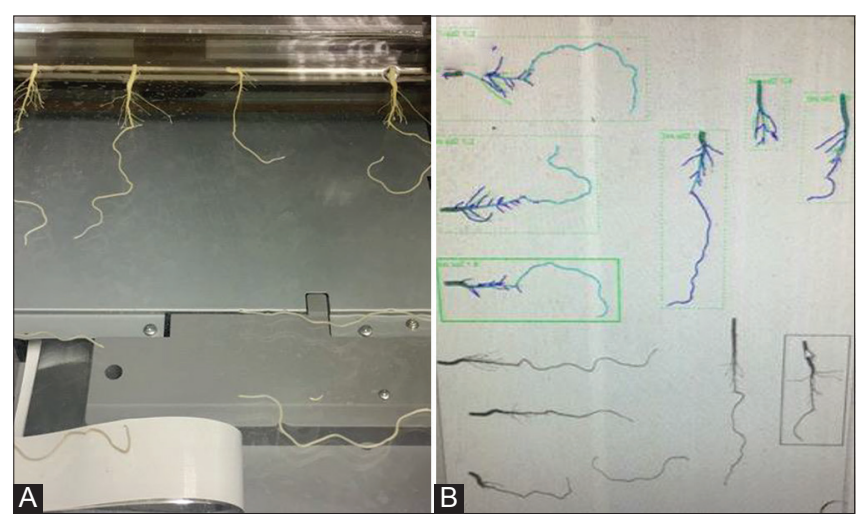

Fig 1. Roots prepared to be digitized into images (A) and analysis of the images by WinRhizo software version $4.1 \mathrm{c}(\mathrm{B})$

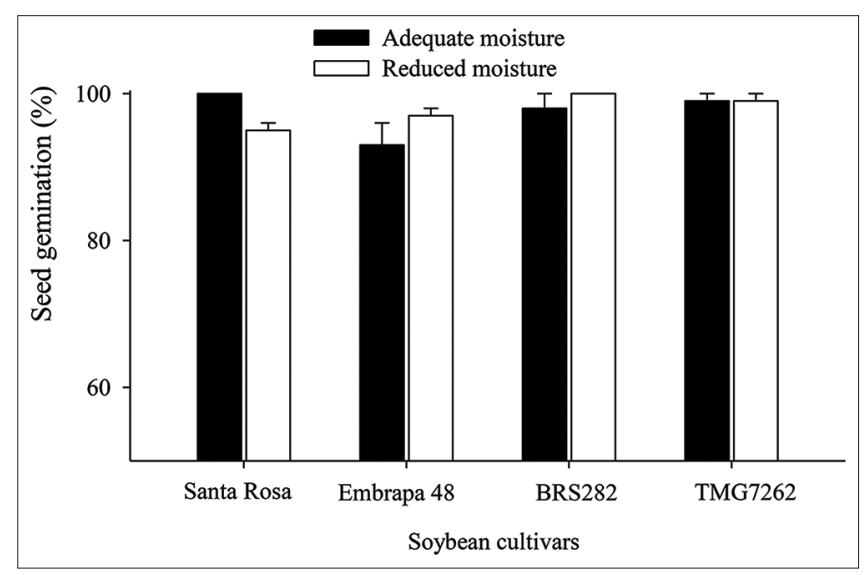

Fig 2. Percent of seed germination of soybean cultivars according to water availability

with water deficit had root volume 1.21 times higher than plants without water deficit (Fig. 3D).

The mean root diameter differed among all cultivars in the following order: Santa Rosa > TMG7262 > BRS282 > Embrapa 48 (Fig. 3E). Different from the other attributes, the mean root diameter reduced 0.95 times due to water deficit (Fig. 3F).

The root length showed interaction between cultivars and water status (Fig. 4A). Under water deficit condition, the root length was higher for cultivars TMG7262 and Embrapa 48. Under the condition without water deficit, the cultivars did not differ from each other. Within the cultivars factor, the following effect was observed: cultivars Santa Rosa, BRS282 and TMG7262 increased the root length in the seedlings submitted to the water deficit, while the cultivar Embrapa 48 did not differ.

The main root length showed interaction between cultivars and water status (Fig. 4B). Under water deficit condition, the main root length was higher for cultivars BRS282 and Embrapa 48. Without water deficit the greatest length in the
Table 1: Analysis of variance between water availability and cultivars for attributes corresponding to root growth, shoot growth and dry biomass

\begin{tabular}{lccc}
\hline Attributes & $\begin{array}{c}\text { Water } \\
\text { availability (W) }\end{array}$ & $\begin{array}{c}\text { Cultivars } \\
\text { (C) }\end{array}$ & $\mathbf{W} \times \mathbf{C}$ \\
\hline Root & $*$ & $*$ & $\mathrm{~ns}$ \\
Projected area & $*$ & $*$ & $\mathrm{~ns}$ \\
Root volume & $*$ & $*$ & $\mathrm{~ns}$ \\
Root diameter & $*$ & $*$ & $*$ \\
Total root length & $\mathrm{ns}$ & $*$ & $*$ \\
Main root length & $*$ & $\mathrm{~ns}$ & $*$ \\
Altitude & $*$ & $\mathrm{~ns}$ & $\mathrm{~ns}$ \\
Number of meristems & & & \\
Shoot & $*$ & $*$ & $*$ \\
Projected area & $*$ & $*$ & $*$ \\
Shoot volume & $*$ & $*$ & $\mathrm{~ns}$ \\
Stem diameter & $\mathrm{ns}$ & & $\mathrm{ns}$ \\
Shoot lenght & & $*$ & $\mathrm{~ns}$ \\
Biomass & $\mathrm{ns}$ & $*$ & $*$ \\
Shoot biomass & $*$ & $*$ & $*$ \\
Root biomass & $\mathrm{ns}$ & & \\
Total biomass & &
\end{tabular}

${ }^{*} p \leq 0.05$; ns: non-significant

main root was observed for the cultivar Embrapa 48. Cultivars Santa Rosa and BRS 282 increased the main root length under water deficit, while the cultivars Embrapa 48 and TMG7262 reduced the main root length under water deficit.

The root altitude also showed interaction between cultivar and water status (Fig. 4C). Under water deficit condition the highest root altitude was observed in the cultivar Santa Rosa. Without water deficit the highest root altitude was observed in the cultivars Embrapa 48 and TMG7262. Within the cultivars the following effect occurred: all the cultivars increased the root altitude under water deficit.

The number of meristems showed only effect for water status (Fig. 4D). For the water deficit condition, the number of meristems increased in all cultivars.

\section{Shoot attributes}

The projected area showed interaction between cultivars and water condition (Fig. 5A). Under water deficit condition, there was no difference between the cultivars in the shoot projected area. For the condition without water deficit the largest projected area was observed in cultivar TMG7262. Within the cultivars the following effect occurred: the shoot projected area was reduced in the water deficit condition for all the cultivars.

The shoot volume showed interaction between cultivars and water conditions (Fig. 5B). In the condition with water deficit the cultivars did not differ among themselves. Without water deficit, the highest volume of shoot was observed for cultivar TMG7262. Within the cultivars, the following effect was 


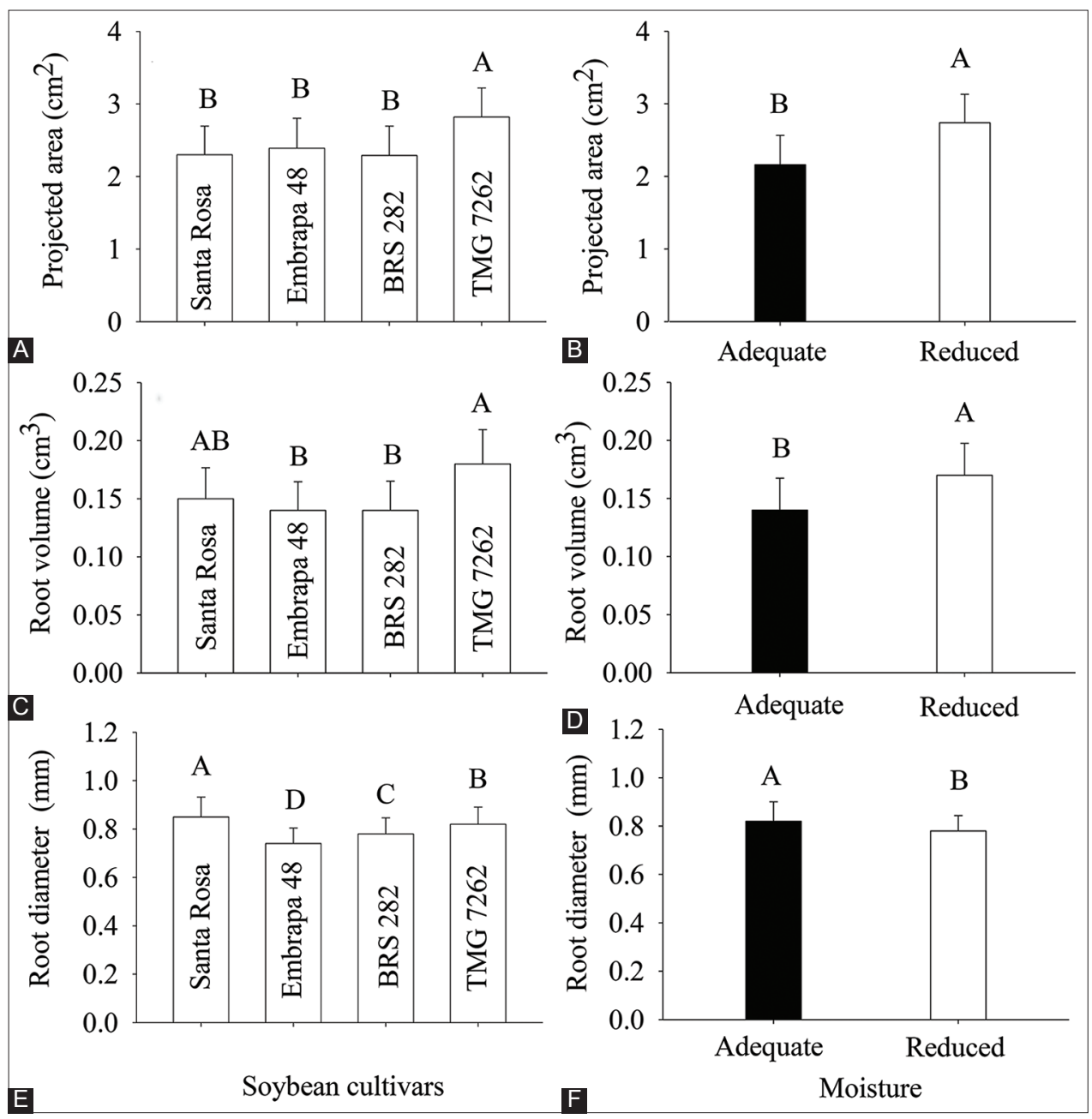

Fig 3. Average root attributes of soybean seedlings according to cultivars and water availability: projected area (A and B), root volume (C and D), and root diameter ( $\mathrm{E}$ and $\mathrm{F})$. Different letters indicate significant difference among treatments according to Tukey test $(p \leq 0.05)$

observed: the TMG7262 cultivar reduced the shoot volume with water deficit, the other cultivars did not differ among themselves in relation to the water availability condition.

The mean stem diameter showed only effect between cultivars and water deficit without interaction (Fig. 5C). The highest mean shoot diameter was observed for cultivar TMG7262. Without water deficit the average shoot diameter was the highest (Fig. 5D).

The shoot length showed effect only for cultivar (Fig. 5E). The highest shoot length was observed for cultivar TMG7262.

\section{Biomass}

Root biomass presented interaction between cultivars and water deficit (Fig. 6A). For the water deficit condition, a heavier root biomass was observed for cultivars BRS282 and TMG7262. Without water deficit the heavier dry root biomass was observed only for cultivar TMG7262. Within the cultivars the following effect was observed: EMBRAPA
48 cultivar, and BRS282, TMG7262 increased root biomass under water deficit, while Santa Rosa did not differ in both water conditions. Shoot biomass presented effect only among the cultivars (Fig. 6B). The heavier shoot biomass was observed for cultivar TMG7262.

For the total biomass there was interaction between water conditions and cultivars (Fig. 6C). With water deficit, the total biomass was heavier for cultivars BRS282 and TMG7262. Without water deficit the total biomass was heavier for the cultivars Santa Rosa and TMG7262. Within the cultivars the following effect occurred: the total biomass increased in the cultivars Embrapa 48 and TMG7262.

\section{DISCUSSION}

\section{Root attributes}

In general, soybean seedlings grown under water deficit conditions presented higher growth of dry mass, length, projected area, volume, meristems and altitude. Root 


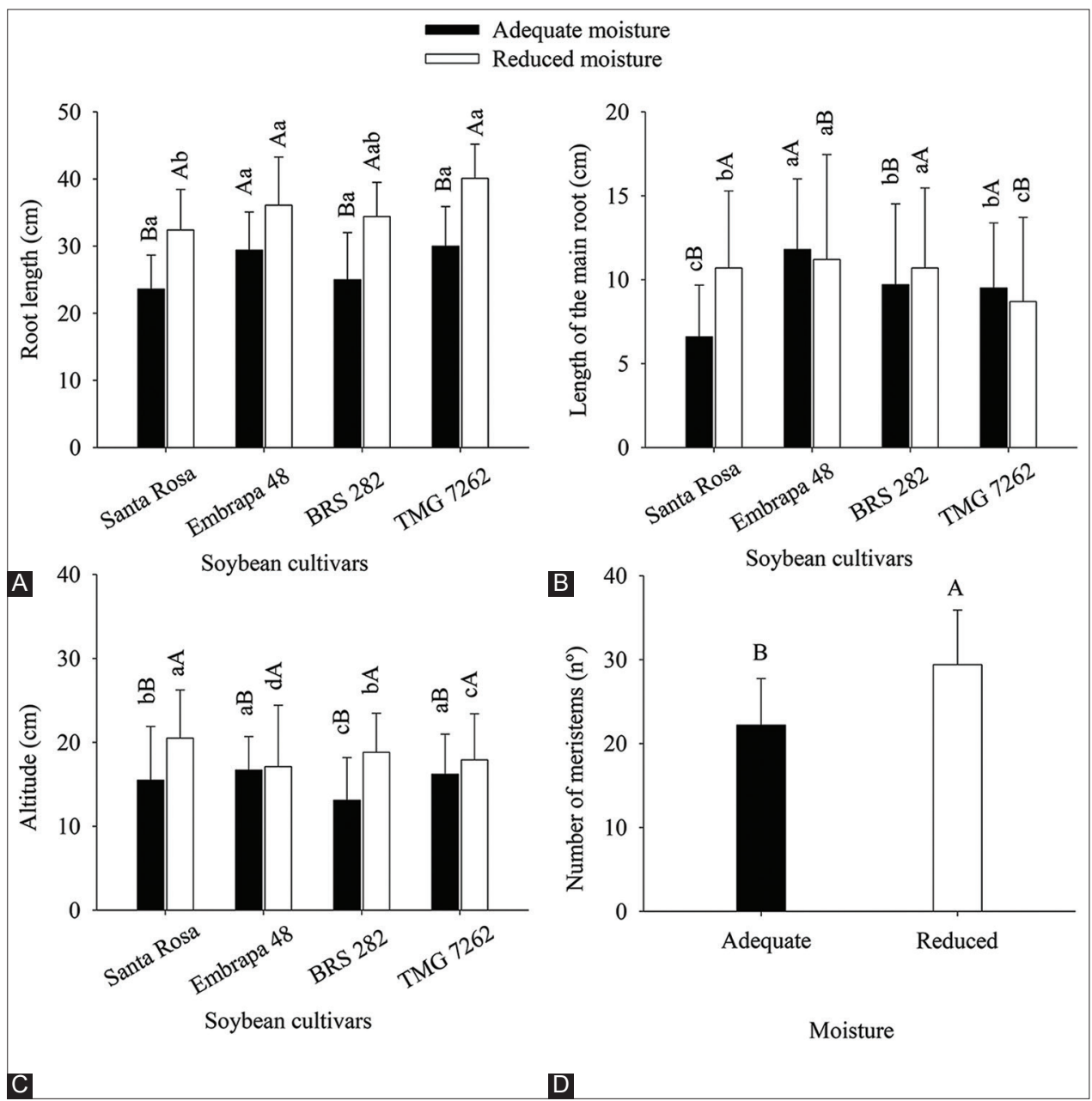

Fig 4. Average root attributes of soybean seedlings according to cultivars and water availability: root length (A and $B)$ and altitude $(C$ and $D)$. Different letters indicate significant difference among treatments according to Tukey test $(p \leq 0.05)$

length of the main root was reduced only for the cultivars Embrapa 48 and TMG7262. However, for evaluations of the aerial part there was no difference between the water conditions, only a small reduction of their development.

Several studies have considered the root length as the most sensitive character for the differentiation of the physiological quality of seeds, due to the drought-tolerant cultivars emit roots even in adverse conditions, allowing their differentiation among sensitive cultivars, which only emit large amounts of roots under ideal growing conditions (Echer et al., 2010).

The root, especially the meristem, is the first organ to detect signs related to water deficit, which triggers rapid changes in gene expression (Schachtman and Goodger 2008; Bencke-Malato et al., 2019; Wang and Komatsu, 2018). For example, Rodrigues et al. (2012) induced the expression of 3089 genes in soybean roots from the simulation of the initial stages of water deficit by using a hydroponic system.

The water deficit can reduce the fresh biomass of leaves and soybean roots (Bencke-Malato et al., 2019). In the same study, these authors verified enzymatic and molecular changes in soybean roots subject to deficit, without altering the fresh biomass of the stems.

The root vigor determines the potential of the roots to grow in the soil layers, altering the distribution of the roots and the potential amount of water that can be absorbed by the roots (Ma et al., 2009). Thus, the selection of cultivars with depth root growth is required to increase the water availability to the plants for genetic improvement (Bortoluzzi et al., 2014).

Under water deficit conditions, plants tend to increase the root biomass in order to cover a larger area in search of water (Taiz et al., 2017), which agrees with our results. Plant growth models suggest that soybean plants with deeper roots can raise yields from 6.6 to $9.4 \%$ (Battisti et al., 2017). Therefore, it is necessary to adapt the cultivars and crop management to reach deeper roots in order to mitigate the effects of water deficit (Fenta et al., 2014, Bortoluzzi et al., 2014; Battisti et al., 2017).

Emir. J. Food Agric • Vol $31 \bullet$ Issue 9 • 2019 


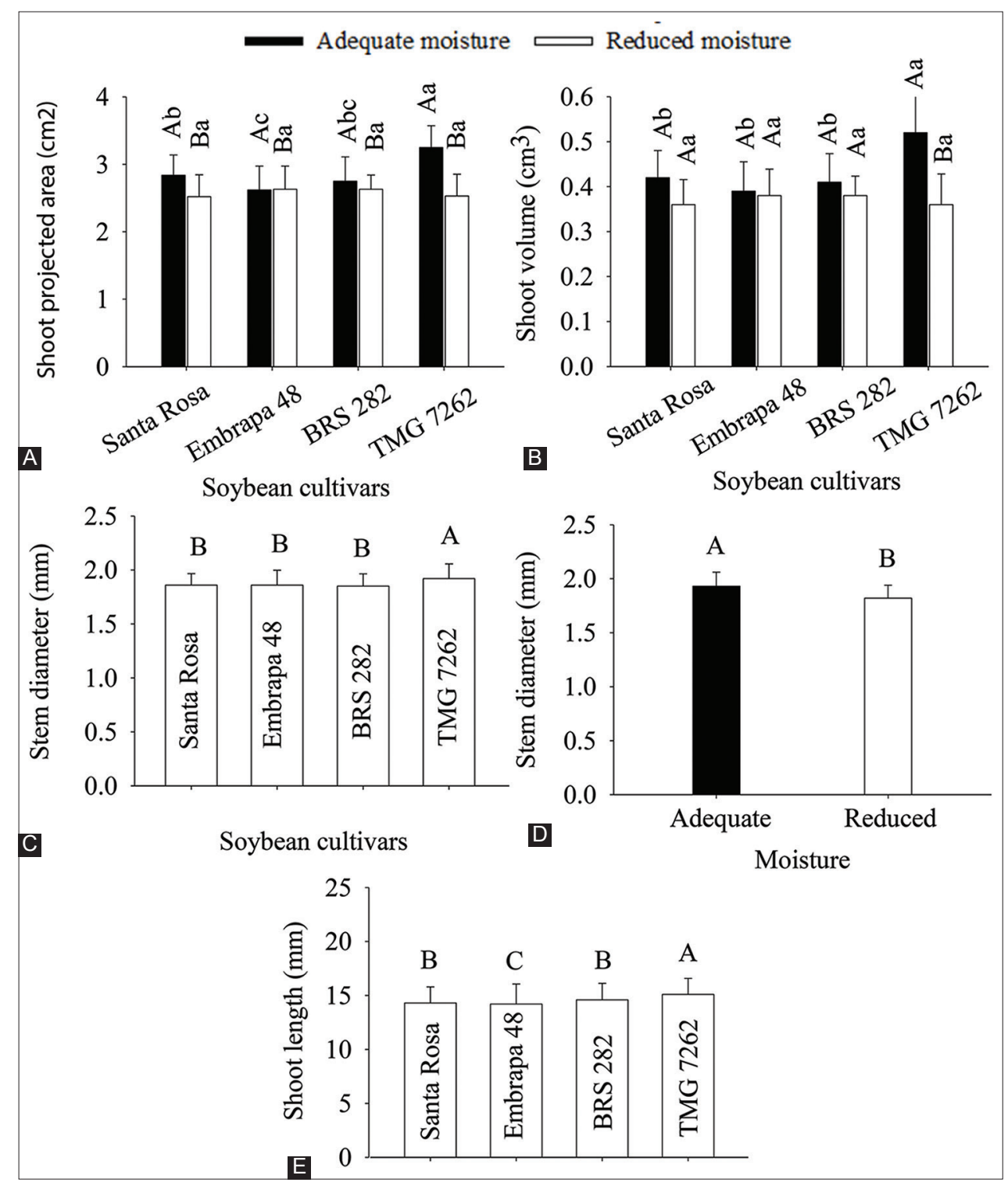

Fig 5. Average shoot attributes of soybean seedlings according to cultivars and water availability: shoot projected area (A), shoot volume (B), stem diameter $(C$ and $D)$, and shoot length $(E)$. Different letters indicate significant difference among treatments according to Tukey test $(p \leq 0.05)$

The water restriction reduced the root attributes of the cultivar Santa Rosa, which is possibly related to the greater sensitivity of this material to the water deficit. The cultivars Embrapa 48 and BRS 282 presented an intermediate response to the water deficit, which showed the relation of the year of release and improvement of soybean cultivars. However more studies with more representative samples of cultivars are needed to characterize the effect of the improvement in the root attributes. Benjamin and Nielsen (2006) showed that in the flowering and grain filling stages, the punctual effect of water deficit may be less pronounced on biomass and root attributes of soybean. Seedlings with greater resilience to the water deficit is an interesting attribute to be sought in future soybean cultivars.

\section{Shoot attributes}

There was a low relation between analysis of shoot attributes to detect the initial damages of the water deficit. For the shoot length there was difference only between cultivars. For attributes such as projected area and shoot volume, a small reduction was observed when the seedlings were subjected to water deficit.

The reduction of soybean biomass under water deficit conditions was related to the decrease of photosynthesis rates, whose energy often is concentrated on the root system (Neumaier and Nepomuceno, 1994). When soybean plants growth on water deficit condition, they trigger a series of biological, biochemical and physiological processes that culminate in changes in specific growth and development according to the plant organ (Wang and 


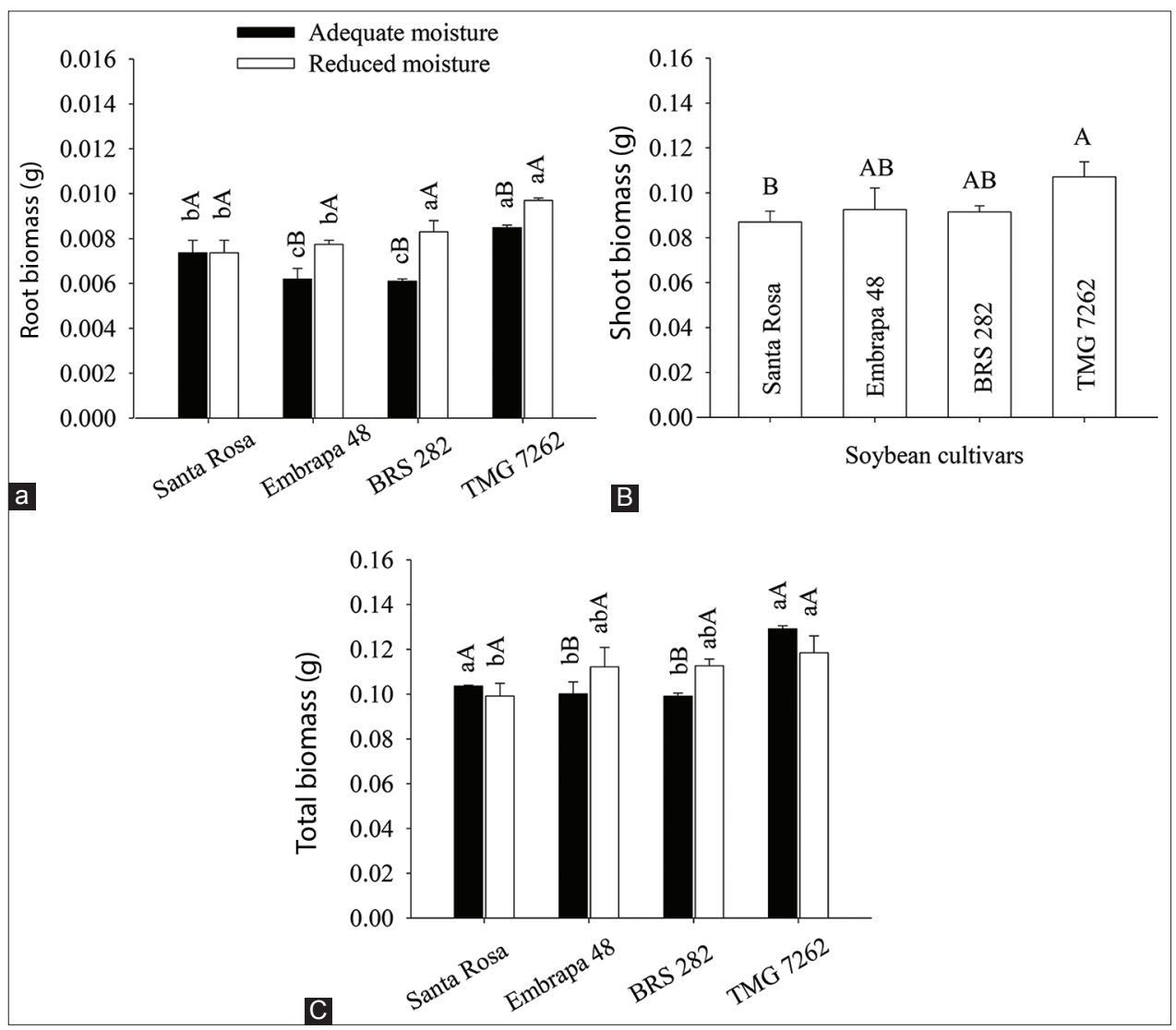

Fig 6. Average dry biomass attributes of soybean seedlings according to cultivars and water availability: root biomass (A), shoot biomass (B), and total biomass (C). Different letters indicate significant difference among treatments according to Tukey test $(p \leq 0.05)$

Komatsu, 2018). Thus, it is difficult to compare changes in root and shoot organs.

Under conditions of water deficit, there is a decrease in stomatal conductance, which reduces the $\mathrm{CO}_{2}$ assimilation and the quantum efficiency of the photosystem II process (Taiz et al., 2017) and water use efficiency (Zhang et al., 2016).

\section{Biomass}

Soybean cultivars responded differently to the water deficit, except the cultivar Santa Rosa, which did not modify the carbohydrate partition for the root in the condition of water deficit. The TMG7262 cultivar (the more recent released material) on the water deficit condition presented the higher values of root dry mass, root length, projected area, root mean diameter and volume. The increase of the root system is one of the attributes desired in modern cultivars to tolerate current and future water deficit, since deeper roots reach soil volumes with higher water content (Battisti et al., 2017).

Several characteristics of soybean cultivars have been altered over the years, resulting in genetic gain such as the higher number of pods and seeds per plant when compared to older cultivars (Suhre et al., 2014, Rincker et al., 2014). Modern soybean cultivars improved the photosynthetic efficiency, through the greater assimilation of $\mathrm{C}$ and $\mathrm{N}$ fixation, optimization of enzymes, lower metabolic expenditure in the respiration process, culminating, in this way, with yield gain (Ainsworth et al., 2012).

The genetic difference for morphological and physiological attributes in roots of soybean was already evidenced in another work (Suematsu et al., 2017), who showed the importance of characterizing the materials with a robust root system to be used as a basis for cultivation improvement programs. The difference among the cultivars can be evidenced by the root/shoot biomass ratio, water use efficiency and intercellular $\mathrm{C}$ concentration in the leaves (Suematsu et al., 2017; Koester et al., 2016).

The greater sensitivity of soybean to the water deficit can reduce the yield (Morando et al., 2014). It can be verified that initial root attributes allow to characterize cultivars with less tolerance to drought at the beginning of crop development.

\section{CONCLUSIONS}

There was interaction between cultivars and water deficit in the initial root growth phase of the soybean crop. The water 
deficit can increase the root length of soybean seedlings, as well as modify the biomass partition. The seedling evaluation method can be used for mass prospecting of cultivars with greater resilience to the water deficit, since it can be evaluated in a short time interval. The cultivars used in this study can be classified from more to less sensitive in relation to the water deficit as follows: Santa Rosa $>$ Embrapa $48=$ BRS $282>$ TMG 7262. The results present a trend for greater resilience in the more modern evaluated cultivars.

\section{ACKNOWLEDGEMENTS}

We acknowledge funding from the São Paulo Research Foundation (FAPESP) - Grant $n^{\circ}$. 2010/11744-2, 2016/06310-0, 2017/24059-5, and 2017/14889-0. We also thank financial support from Coordination for the Improvement of Higher Education Personnel (CAPES) and from National Counsel of Technological and Scientific Development (CNPq) - Grant no. 140209/2015-8).

\section{Authors' Contributions}

Conceptualization: Umburanas, R. C.; Dourado-Neto, D.; Reichardt, K. Data acquisition: Umburanas, R. C.; Donegá, V. C.; Queiroz, V. M. Data analysis: Umburanas, R. C.; Donegá, V. C.; Queiroz, V. M.; Fontana, D. C. Design of Methodology: Umburanas, R. C.; Dourado-Neto, D.; Reichardt, K. Writing and editing: Umburanas, R. C.; Fontana, D. C.; Bampi, D.; Reichardt, K.

\section{REFERENCES}

Ainsworth, E. A., C. R. Yendrek, J. A., Skoneczka and S. P. Long. 2012. Accelerating yield potential in soybean: Potential targets for biotechnological improvement. Plant Cell. Environ. 35: 38-52.

Battisti, R., P. C. Sentelhas, K. J. Boote, G. M. D. Câmara, J. R. Farias and C. J. Basso. 2017. Assessment of soybean yield with altered water-related genetic improvement traits under climate change in Southern Brazil. Eur. J. Agron. 83: 1-14.

Bencke-Malato, M., A. P. De Souza, M. Ribeiro-Alves, J. F. Schmitz, M. S. Buckeridge and M. Alves-Ferreira. 2019. Short-term responses of soybean roots to individual and combinatorial effects of elevated $\left[\mathrm{CO}_{2}\right]$ and water deficit. Plant Sci. 280: 283-296.

Benjamin, J. G. and D. C. Nielsen. 2006. Water deficit effects on root distribution of soybean, field pea and chickpea. Field Crops Res. 97: 248-253.

Bortoluzzi, E. C., G. L. Parize, J. Korchagin, V. R. D. Silva, D. D. S. Rheinheimer and J. Kaminski. 2014. Soybean root growth and crop yield in reponse to liming at the beginning of a no-tillage system. Rev. Bras. Ciênc. Solo. 38: 262-271.

Brasil. (2009), Ministério da Agricultura, Pecuária e Abastecimento. Regras Para Análise de Sementes. Secretaria de Defesa Agropecuária, Brasília.

Broetto, F., E. R. Gomes and T. A. C. Joca. 2017. Estresse Das Plantas: Teoria and Pratica. Cultura Acadêmica Editora Unesp, São Paulo.
Bouma, T. J., K. L. Nielsen and B. A. S. Koutstaal. 2000. Sample preparation and scanning protocol for computerized analysis of root length and diameter. Plant Soil. 218: 185-196.

Chaves, M. M., J. Flexas and C. Pinheiro. 2009. Photosynthesis under drought and salt stress: Regulation mechanisms from whole plant to cell. Ann. Bot. 103: 551-560.

Dai, A. 2013. Increasing drought under global warming in observations and models. Nat. Clim. Change. 3: 52.

Echer, F. R., C. C. Custódio, S. T. Hossomi, J. C. Dominato and N. B. M. Neto. 2010. Estresse hídrico induzido por manitol em cultivares de algodão. Rev. Cienc. Agron. 41: 638-645.

FAOSTAT. 2019. Crops and Livestock Products. Available from: http://www.fao.org/faostat/en/\#data/TP. [Last accessed on 2019 Feb 10].

Ferreira, D. F. 2008. Sisvar Sistema De Análise De Variância. Versão 5.3, Lavras.

Fenta, B. A., S. E. Beebe, K. J. Kunert, J. D. Burridge, K. M. Barlow, P. J. Lynch and C. H. Foyer. 2014. Field phenotyping of soybean roots for drought stress tolerance. Agron. 4: 418-435.

Foyer, C. H., H. M. Lam, H. T. Nguyen, K. H. M. Siddique, R. Varshney, T. D. Colmer and J. W. Cooper. 2016. Neglecting legumes has compromised global food and nutritional security. Nat. Plants. 2: 1-10.

Franco, J. A., S. Bañón, M. J. Vicente, J. Miralles and J. J. Martínez-Sánchez. 2011. Root development in horticultural plants grown under abiotic stress conditions a review. J. Hortic. Sci. Biotechnol. 86: 543-556.

Jha, P. K., S. N. Kumar and A. V. Ines. 2018. Responses of soybean to water stress and supplemental irrigation in upper indogangetic plain: Field experiment and modeling approach. Field Crops Res. 219: 76-86.

Koester, R. P., B. M. Nohl, B. W. Diers and E. A. Ainsworth. 2016. Has photosynthetic capacity increased with 80 years of soybean breeding? An examination of historical soybean cultivars. Plant Cell. Environ. 39: 1058-1067.

Ku, Y. S., W. K. Au-Yeung, Y. L. Yung, M. W. Li, C. Q. Wen and X. Liu. 2013. Drought stress and tolerance in soybean. In: J. E. Board (Ed.), A Comprehensive Survey of International Soybean Research Genetics, Physiology, Agronomy and Nitrogen Relationship. Plenum Press, New York.

Ma, L., G. Hoogenboom, S. A. Saseendran, P. N. S. Bartling, L. R., Ahuja and T. R. Green. 2009. Effects of estimating soil hydraulic properties and root growth factor on soil water balance and crop production. Agron. J. 101: 572-583.

Morando, R., A. O. da Silva, L. C. Carvalho and M. P. Pinheiro. 2014. Water deficit: Effect on soybean crop. J. Agron. Sci. 3: 113-129.

Neumaier, N. and A. L. Nepomuceno. 1994. Water management. In: Tropical Soybean: Improvement and Production. FAO Plant Production and Protection Series, No. 27. Food and Agriculture Organization, Rome, United Nations.

Ray, D. K., N. D. Mueller, P. C. West and J. A. Foley. 2013. Yield trends are insufficient to double global crop production by 2050 . PLoS One. 8: 1-8.

Rincker, K., R. Nelson, J. Specht, D. Sleper, T. Cary, S. R. Cianzio, S. Casteel, S. Conley, P. Chen, V. Davis, C. Fox, G. Graef, C. Godsey, D. Holshouser, G. L. Jiang, S. K. Kantartzi, W. Kenworthy, C. Lee, R. Mian, L. McHale, S. Naeve, J. Orf, V. Poysa, W. Schapaugh, G. Shannon, R. Uniatowski, D. Wang and B. Diers. 2014. Genetic improvement of US soybean in maturity groups II, III, and IV. Crop Sci. 54: 1419-1432.

Rodrigues, F. A, J. Marcolino, J. F. C. Carvalho, C. Nascimento, N. Neumaier, J. R. B. Faria, M. F. Carazzolle, F. C. Marcelino and 
A. L. Nepomuceno. 2012. Using subtractive libraries to prospect differentially expressed genes in soybean plants submitted to water deficit. Genet. Mol. Biol. 35: 304-314.

Schachtman, D. P. and J. Q. Goodger. 2008. Chemical root to shoot signaling under drought. Trends Plant Sci.13: 281-287.

Sediyama, T., J. S. Glasenapp and E. Matsuo. 2015. Estresse abiótico. In: T. Sediyama (Ed.), Melhoramento Genético da Soja. Mecenas, Londrina.

Suematsu, K., T. Abiko, V. L. Nguyen and T. Mochizuki. 2017. Phenotypic variation in root development of 162 soybean accessions under hypoxia condition at the seedling stage. Plant Prod. Sci. 20: 323-335.

Suhre, J. J., N. H. Weidenbenner, S. C. Rowntree, E. W. Wilson, S. L. Naeve, S. P. Conley, S. N. Casteel, B. W. Diers, P. D. Eskere, J. E. Specht and V. M. Davis. 2014. Soybean yield partitioning changes revealed by genetic gain and seeding rate interactions. Agron. J. 6: 1631-1642.

Taiz, M., E. Zeiger, I. M. Mooler and A. Murphy. 2017. Plant Physiology. $6^{\text {th }}$ ed. Artmed., Porto Alegre.

Thu, N. B. A., Q. T. Nguyen, X. L. T. Hoang, N. P. Thao and L. S. P. Tran. 2014. Evaluation of drought tolerance of the Vietnamese soybean cultivars provides potential resources for soybean production and genetic engineering. BioMed Res. Int. 2014: 1-9.

Wang, X. and S. Komatsu. 2018. Proteomic approaches to uncover the flooding and drought stress response mechanisms in soybean. J. Proteomics. 172: 201-215.

Wheeler, T. and J. von Braun. 2013. Climate change impacts on global food security. Science. 341: 508-513.

Zhang, J., J. Liu, C. Yang, S. Du and W. Yang. 2016. Photosynthetic performance of soybean plants to water deficit under high and low light intensity. S. Afr. J. Bot. 105: 279-287. 